\title{
The effect of dynamic assessment on L2 learners' listening comprehension
}

\author{
Ali Roohani, Bashir Jam, Shiva Yeganeh Shahbaz, Masoud Rahimi Domakani \\ Shahrekord University, Iran
}

(Text received December 07 2018; accepted September 25 2018; final version

December 19 2018)

DOI: https://doi.org/10.5565/rev/jt13.751

\begin{abstract}
Group dynamic assessment (G-DA), which is grounded in Vygotsky's sociocultural theory (SCT), explores the role of social interaction and collaboration in the development of participants' listening performance. This study aimed to investigate the effectiveness of G-DA approach on listening comprehension of English as a foreign language(EFL) learners in two time intervals. To this end, twenty learners were selected from among Iranian EFL learners at an English language institute. The quantitative data analysis revealed that mediational strategies which were offered to learners within the group's Zone of Proximal Development (ZPD) could enhance their listening comprehension. These findings have important implications for all classroom teachers who can benefit from different designs of integrating instruction and assessment through offering mediational strategies to assist L2 learners in the development of their listening skill.
\end{abstract}

Keywords: dynamic assessment, zone of proximal development, listening comprehension

Resum: L'avaluació dinàmica en grup (G-DA), que es fonamenta en la teoria sociocultural (SCT) de Vygotsky, explora el paper de la interacció i la col·laboració socials en el desenvolupament de l'actuació de la comprensió oral dels participants. Aquest estudi investiga l'efectivitat de l'aproximació G-DA en la comprensió oral dels aprenents d'anglès com a llengua estrangera (EFL) en dos intervals de temps. Amb aquesta finalitat es van seleccionar una vintena d'aprenents d'EFL iranians en un centre d'ensenyament d'anglès. L'anàlisi de les dades quantitatives va revelar que les estratègies de mediació que es van oferir als aprenents enquadrats a la zona de desenvolupament pròxim (ZDP) del grup van poder millorar la comprensió oral. Aquests resultats tenen implicacions importants per a tots els professors, que es poden beneficiar de les diferents maneres d'integrar instrucció i avaluació oferint d'estratègies de mediació per ajudar els alumnes d'L2 a l'hora de treballar les habilitats de comprensió oral.

Paraules clau: avaluació dinàmica, zona de desenvolupament pròxim, comprensió oral

Resumen: La evaluación dinámica en grupo (G-DA), que se fundamenta en la teoría sociocultural (SCT) de Vygotsky, explora el papel de la interacción y la colaboración sociales en el desarrollo de la actuación de la comprensión oral de los participantes. Este estudio investiga la efectividad de la aproximación G-DA en la comprensión oral de los aprendices de inglés como lengua extranjera (EFL) en dos intervalos de tiempo. Con esta finalidad se seleccionaron una veintena de aprendices de EFL iraníes en una centro de enseñanza de inglés. El análisis de los datos cuantitativos reveló que las estrategias de mediación que se ofrecieron a los aprendices encuadrados en la zona de desarrollo próximo (ZDP) del grupo pudieron mejorar la comprensión oral. Estos resultados tienen implicaciones importantes para todos los profesores, que se pueden 
beneficiar de las diferentes maneras de integrar instrucción y avaluación ofreciendo estrategias de mediación para ayudar a los alumnos de L2 cuando trabajan las habilidades de comprensión oral.

Palabras clave: evaluación dinámica, zona de desarrollo próximo, comprensión oral

\section{Introduction}

Group dynamic assessment (G-DA) in language learning offers a new insight into language teaching and assessment and also seeks to identify the skills that learners possess as well as their learning potential. It is based on Vygotsky's sociocultural theory (SCT) of mind which strongly proposes "the relationship between social interaction and cognitive development including language learning" (Richards \& Schmidt, 2002, p. 493). G-DA is an approach whereby a teacher not only discovers where learners encounter problems but also provides support to overcome them. By drawing upon the zone of proximal development (ZPD), the mediator engages with learners in a collaborative talk and offers gradual and step-by-step assistance where problems arise. Consequently, learners will be able to do the same task without assistance in the future (Lantolf, 2005). There is some evidence (see Alavi et al., 2012\&Hashemishahraki et al., 2015) that G-DA with emphasis on the process of learning, could have the potential to overcome the problems learners faced during second/foreign language (L2) listening comprehension.

Despite the fact that listening comprehension is an important language skill, L2 learners have recognized it as the most difficult language skill to learn (Hasan, 2000; Vandergrift, 2007). L2 learners usually complain that a spoken text is difficult to understand and attribute their listening problems merely to the speed of speaking. Indeed, they are not aware of important factors behind their listening problems (Hasan, 2000). For this reason, as Vandergrift (2007) claims, there is a need to shed light on the process of listening comprehension and track L2 learner's problems impeding the comprehension. Although some researches explored the effectiveness of G-DA in listening comprehension, it appears that more in-depth studies are needed to apply this approach in the classroom. Therefore, this study sought to gain some insights on how GDA interactions may be organized for L2 learners to function within a class ZPD. 


\section{Literature review}

A process-oriented approach provides a new perspective into the ways L2 learners deal with the difficulties they face during listening process. In order to gain more insights into the process of listening comprehension Vandergrift (2007) suggests qualitative methods which shed light on the process of listening. Moreover, Alderson (2005) states that in order to determine the source of comprehension problems and to help them make progress in listening comprehension, diagnostic tests are needed. According to Alderson (2005), "even those who would concentrate on understanding classroom assessment procedures have failed to address the need for diagnosis of learner's strengths and weaknesses" (p. 2). Therefore, a theory of development is required to have a proper diagnosis of learners' strengths and weaknesses (Alderson, 2005). To respond to aforementioned concerns, this study applied SCT, whereby L2 learners' failures together with the factors involved in their development were considered.

With the emergence of SCT in language learning, the attention is turned to the view that target language interaction plays a central role in language learning. It differs from the interactionist approach in which interaction views as facilitative (Nassaji, 2016). According to Ellis (2009), from the sociocultural perspective, learning "is viewed as a process that occurs in rather than as a result of interaction" (Nassaji, 2016, p. 4). However, similar to the interactionist approach it assigns a significant role to comprehension and sees L2 learner as an active agent in the process of meaning construction based on his/her purpose of text comprehension. The major principle of Vygotsky's theory is that "human consciousness arises through the dialectical unity of our biological endowed brain and auxiliary stimuli appropriated during participation in social practice" (Lantolf \& Poehner, 2014, p. 8). Therefore, both brain and social environment are considered as "the source of development" (Vygotsky, 1994, p. 349). Put more simply, learning takes place under the guidance of an expert and development occurs where L2 learners regulate mental and social activity as a result of internalization of that guidance (Mitchell \& Myles, 2004). Lantolf \& Poehner, (2014) mention:

It is a theory that explains human psychology including L2 development as the dialectical unity of a biologically endowed brain functioning with socially generated 
forms of mediation that give rise to what Vygotsky called higher forms of thinking where human deploy mediation appropriated through social activity to control their mental functioning (p. 7).

Central to SCT are the collaborative tasks which learners participate in (Ellis, 2003). In this way, learners would be successful in performing a task which they could not perform alone. Therefore, scaffolding with attention to cognitive aspects of a task and affective states of a person is a dialogic process which helps learners in performing a task that they are not able to do alone (Ellis, 2003). SCT claims that "whenever individuals perform a task they construct the activity in terms of their motives and goals" (Ellis, 2003, p. 187) and this is what Leontiev (1981) knowns as activity theory. As a result, according to Wang (1996, cited in Donato 2000) the same task is realized differently by different group members due to the way they approach the task.

In the decades following Vygotsky's death, a number of reforms have been carried out in pedagogical system. Meanwhile, a fruitful approach is dynamic assessment (DA) wherein instruction and assessment are viewed in a different way. This approach offers the unification of assessment and instruction. According to Poehner (2008), "This integration occurs as intervention embedded within the assessment procedure in order to interpret individual's abilities and lead them to higher levels of functioning” (p. 5). In other words, in SCT the development occurs as a result of the process of internalization. Moreover, in this approach learners' development is considered as the major feature and all educational activities go around it. Vygotsky's theory realizes that "observing learners engaged in independent problem solving activity revealed those functions that had already been internalized but indicated nothing about abilities that were still in the process of development" (Poehner, 2008, p. 5). Therefore, the various forms of support are offered to learners as instructional intervention and promote their abilities. Thus, instruction has a leading role in development (Poehner, 2008).

As Vygotsky (1998) argued, instruction should operate within the ZPD to help leaners develop. In this way, ZPD provides a framework for the integration of teaching and assessment through which learners perform beyond their present abilities (Poehner, 
2009). Although, Vygotsky (1998) describes ZPD as "the optimum time for teaching both the group and each individual" (p. 204), the numerous studies have done a dyadic or one-to-one model of DA. This model is regarded as an unrealistic model of DA for teaching in classroom since teacher should manage a class with 15 to 30 learners. Therefore, moving from a one-to-one model of teaching to a group-based teaching has been the focus of most research to DA. These two models follow the same general principle but they differ in that G-DA takes into account the group's ZPD (Poehner, 2009).

In G-DA teacher engages the group in an activity in which all members require mediation. In this way, teacher offers mediation in response to the difficulty of one of the learners in the group. Poehner (2009) asserted that this interaction is the primary interaction. Since the primary interaction takes place in the social classroom and before other learners, it has been mediated for the rest of the class as well which is called secondary interaction (Poehner, 2009). Clearly the forms of mediation needed by each learner vary from another one (Poehner, 2009). Therefore, he mentions that the teacher should engage the entire group in interaction to promote their development. He further claims that "G-DA's contribution to L2 education is that it renders classroom interactions more systematic and more attuned to learner's emergent abilities" (p. 488).

To illustrate, Alavi et al. (2012) focused on L2 listening ability and implemented a concurrent interactionist G-DA to a group of intermediate learners in a pretestenrichment-posttest-transfer format. In each session, 15 learners listened to an authentic text selected from VOA broadcasts. Then the teacher replayed the listening text portion by portion and asked them to provide their recalls either in L1 or L2. Upon the learners' failure to recall the text, the teacher offered hints, prompt, and leading questions. Moreover, they were told that their active participation in the class would be scored, and their silence would be considered as the inability to understand the text. Following the analysis of interactions, they reported an inventory of mediational strategies which included different forms of implicit and explicit feedback adopted from Aljaafreh and Lantolf (1994) which are as follow: (a) confirming/rejecting response; (b) replaying; (c) putting words together; (d) repeating the erroneous guess with a questioning tone; (e) 
offering contextual reminders; (f) offering metalinguistic reminders; (g) using dictionary; and (h) providing correct response and explanation. The result also revealed that learners benefited from cooperative scaffolding to promote their listening comprehension.

Moreover, Hashemi Shahraki et al., (2015) explored the implementation of DA by English as a foreign language (EFL) learners at different proficiency levels in the context of listening comprehension. To this end, mediational strategies were given to three experimental groups during nine-week G-DA procedures. The quantitative data analysis revealed that the experimental groups developed significantly in listening comprehension. Also, it was found that the level of proficiency of learners did not have a significant effect on learners' listening gains.

Despite the importance of using a process-oriented approach, such as G-DA in promoting L2 learners' listening comprehension, it is revealed that this approach has not received the attention it truly deserved in L2 classroom (Ableeva, 2010; Poehner, 2005; Taheri, 2016). In order to have a deeper understanding of the problems EFL learners faced during G-DA, this study addressed the following research question:

Is there any significant difference between listening comprehension of EFL learners in two time intervals?

\section{Method}

\section{Participants}

To achieve the purpose of this study, one intact class at an English language institute in Isfahan which consisted of 20 Iranian EFL learners, was selected. The learners were in the age range of 20-26. In order to ensure their proficiency level, an oxford placement test (OPT) was administered.

\section{Instruments}

The OPT (Allen, 1992) was used to determine participants' proficiency levels. It consisted of two sections namely grammar and listening. Besides, a TOEFL test, selected from ETS TOEFL (2003), was selected. It comprised 50 multiple-choice items 
and was administered as the pretest and posttest. Moreover, six listening tasks followed by some multiple-choice comprehension questions were administered to the participants.

\section{Procedure}

This study applied a concurrent interactionist G-DA approach to measure participants' performances in listening comprehension. To do so, after the administration of the OPT at the beginning of the program, in week one a TOEFL test selected from ETS TOEFL book (2003) was given to all the participants to determine their IP abilities. The reliability of this test was 0.77 which was computed using Cronbach's alpha formula. This test was also given to two testing experts to review and judge. After the participants answered the pretest individually, the test sheets were collected. Then, the listening tests were replayed for them to provide their recalls in order to perform this test dynamically. During the enrichment phase they received the listening tasks in three sessions. In each session, they performed a listening task at first in ND (nondynamic) format, then they performed that listening task through G-DA procedure. This is completely in accordance with Poehner's (2005) idea that DA procedure has the potential to measure the participants' ZAD (zone of actual development) and also ZPD. In this procedure, whenever the participants faced listening problems, the mediator offered mediational strategies to move them to higher levels of functioning. The strategies used in this study were taken from Aljaafreh and Lantolf (1994) and were arranged from the most implicit to the most explicit. Following the enrichment phase, the pretest was administered again as a posttest to the participants to reveal the effects of the enrichment phase on L2 listening comprehension. Regarding all tests of the study the researcher considered one score for each item.

\section{Results}

In order to explore the impact of G-DA on listening comprehension of EFL learners, the quantitative analysis of the data was obtained through the SPSS (version 20). To do so, descriptive statistics, first, were calculated to ensure any violation of preliminary 
normality assumptions. The results of this analysis are summarized in Table 1. As Table 1 indicates, the mean for the participants before enrichment is 28.45 while the mean after the enrichment is 32.70. Moreover, more variety revealed among the scores before enrichment as compared to the scores after enrichment. The results of skewness and kurtosis values and the Kolmogorov-Smirnov statistics indicated that the scores were normally distributed.

Table 1. Descriptive statistics

N Min Max Mean SD Skewness Kurtosis

\begin{tabular}{llllllll}
\hline Scores (time1) & 20 & 13 & 41 & 28.45 & 7.10 & -.307 & -.175 \\
\hline Scores (time2) & 20 & 21 & 44 & 32.70 & 6.49 & -.232 & -.742
\end{tabular}

A paired sample t-test was conducted to compare the performance of the participants after receiving G-DA approach. As Table 2 shows, there was a significant difference in their listening comprehension scores from time $1(\mathrm{M}=28.45, \mathrm{SD}=7.10)$ to time $2(\mathrm{M}=$ $32.70, \mathrm{SD}=6.49), t(19)=-9.46, \mathrm{p}<.0005$ (two-tailed). The mean difference in two scores was -4.25 with a $95 \%$ interval ranging from -5.17 to -3.32 . The eta squared statistics (.82) indicated a large effect size.

Table 2. Paired sample t-test

Pair $1 \quad$ Mean SD Std. Error Mean $t \quad d f \quad$ Sig. (2-tailed)

\begin{tabular}{lllllll}
\hline Time1- Time2 & -4.25 & 1.97 & .44 & -9.46 & 19 & .000
\end{tabular}




\section{Discussion and conclusion}

The research question posed in this study investigated whether participants' scores could enhance after receiving G-DA procedure. The results of quantitative analysis revealed a significant change in the listening comprehension of the participants. In other words, the mean scores of the participants demonstrated an increase after the enrichment phase. Their improved scores in the posttest could mainly be attributed to the mediation offered during G-DA. The effectiveness of this approach in listening comprehension performance is in line with the previous research (Alavi et al., 2012; Hashemi Shahraki et al., 2015). The findings also showed that engaging the participants in collaborative dialogues and providing mediational strategies create a group ZPD through which the participants performed beyond their current level of functioning. In addition, the interaction between the mediator and the participants within a group ZPD provides a situation for detecting the sources of poor performance of the participants which is hidden during static approach.

The findings of the current study may suggest some pedagogical implications for teachers in classroom. In simpler terms, teachers can benefit from different designs of integrating instruction and assessment through offering mediational strategies to assist L2 learners in development of listening skill.

It is essential to note the constraints and limitations of this study. Firstly, this study was limited to the population of 47 L2 learners studying in a language institute. Because of the lack of facility, it was not possible to carry out such research with larger number of participants. For instance, the time allocated to such G-DA activities were so limited. Secondly, since internalization is not about something moving exclusively inside the head but is about an individual's ability to transfer what they have appropriated in a social circumstance to a new and more difficult social circumstance and function independently, in this study, this claim could be made whether L2 learners could transfer the gained mediational strategies into a transcendence task (Lantolf, 2005). 


\section{References}

Ableeva, R. (2010). Dynamic assessment of listening comprehension in second language learning. Unpublished doctoral dissertation, The Pennsylvania State University, University Park: PA.

Alavi, S. M., Kaivanpanah, Sh., \& Shabani, K. (2012). Group dynamic assessment: an inventory of mediational strategies for teaching listening. The Journal of Teaching Language Skills, 3(4), 27-58.

Alderson, J. C. (2005). Diagnosing foreign language proficiency: The interface between learning and assessment. London: Continuum.

Aljaafreh, A., \& Lantolf, J. P. (1994). Negative feedback as regulation and second language learning in the zone of proximal development. The Modern Language Journal, 78(4), 465-83.

Donato, R. (2000). Sociocultural contribution to understanding the foreign and second language classroom. In J. P. Lantolf (Ed), Sociocultural theory and second language learning, (pp. 27-50). Oxford University Press.

Ellis, R. (2003). Task-based language learning and teaching. New York, Oxford University Press.

Ellis, R. (2009). Corrective feedback and teacher development. L2 Journal, 1, 3-18.

Hasan, A. (2000). Learners' perceptions of listening comprehension problems. Language, Culture and Curriculum,13, 137-153.

Hashemi Shahraki, S., Ketabi, S. \& Barati, H. (2015). Dynamic assessment in EFL classrooms: Assessing listening comprehension in three proficiency levels. International Journal of Research Studies in Education, 4(3), 17-31.

Lantolf, J. P. (2005). Sociocultural and second language learning research: An exegesis. In E. Hinkel, (Ed), Handbook of research in second language teaching and learning, (pp. 335-350). Mahwah: New Jersey.

Lantolf, J. P., \& Poehner, M. E. (2014). Sociocultural theory and the pedagogical imperative in L2 education: Vygotskian praxis and the research/practice divide. New York: Routledge.

Leontiev, A. A. (1981). Psychology and language learning process. London: Pergamon. 
Mitchell, R., \& Myles, F. (2004). Second language learning theories (2nd.). London: Hodder Arnold.

Nassaji, H. (2016). Anniversary article Interactional feedback in second language teaching and learning: A synthesis and analysis of current research. Language Teaching Research, 20(4), 535-562.

Poehner, M. E. (2005). Dynamic assessment of oral proficiency among advanced L2 learners of French. Unpublished doctoral dissertation. The Pennsylvania State University, University Park, PA.

Poehner, M. E. (2008). Dynamic assessment. A Vygotskian approach to understanding and promoting L2 development. Springer: USA.

Poehner, M. E. (2009). Group dynamic assessment: Mediation for the L2 classroom. TESOL Quarterly, 43(3), 471-491.

Richards, J. C., \& Schmidt, R. (2002). Longman dictionary of applied linguistics and language teaching ( $3^{\text {rd }}$ ed.). NY: Cambridge University Press.

Taheri, P. (2016). Dynamic assessment: A more comprehensive approach to interpret and capture L2 listening comprehension development. International Journal of Sciences and Research, 72(12), 10-25.

Vandergrift, L. (2007). Recent development in second and foreign language listening comprehension research. Language Teaching, 40(3), 191-210.

Wang, J. (1996). Same task: Different activities. Unpublished research report, University of Pittsburgh, Pittsburgh, PA.

Vygotsky, L. S. (1994). The problem of the environment. In J. van der Veer \& J. Valsiner (Eds.), The Vygotsky reader, (pp. 338-354). Oxford: Blackwell.

Vygotsky, L. S. (1998). The problem of age. In R. W. Rieber (Ed.), The collected works of L. S. Vygotsky: Vol. 5: Child psychology, (pp. 187-205). New York: Plenum.

\section{Authors' information}

Ali Roohani is a PhD holder in TEFL. He received his BA in English literature, his MA and PhD in TEFL from Shiraz and Allameh Tabataba'ii universities, respectively. He is currently a faculty member at Shahrekord University. His area of interest includes EQ, multiple intelligences, burnout, language 
learning strategies, materials development and textbook evaluation. He has published 4 books and 49 papers and presented a number of papers in the national and international conferences.

Email: roohani.ali@gmail.com / roohani-a@lit.sku.ac.i

Bashir Jam is a PhD holder in TEFL. He is currently a faculty member at Shahrekord University.

Email: b_jam47@yahoo.com

Shiva Yeganeh Shahbaz is an M.A. student of TEFL at Shahrekord University. She has been teaching English for five years.

Email: Shivayeganeh7@gmail.com

Masoud Rahimi Domakani is a PhD holder in TEFL. He is currently a faculty member at Shahrekord University.

Email: rahimi@lit.sku.ac.ir

To cite this article:

Roohani, A., Bashir, J., Yeganeh Shahbaz, S., \& Rahimi Domakani, M. (2018). The effect of dynamic assessment on L2 learners' listening comprehension. Bellaterra Journal of Teaching \& Learning Language \& Literature, 11(4), 59-70. DOI: https://doi.org/10.5565/rev/jt13.751

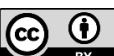

